D. W. PIOTROWSKI*ET AL. (PFIZER WORLDWIDE RESEARCH \& DEVELOPMENT, GROTON, USA)

PF-07059013: A Noncovalent Modulator of Hemoglobin for Treatment of Sickle Cell Disease

J. Med. Chem. 2021, 64, 326-342, DOI: 10.1021/acs.jmedchem.0c01518.

\title{
Category
}

Synthesis of Natural

Products and

Potential Drugs

\section{Synthesis of PF-07059013}

Synthesis of fragment $F$ :

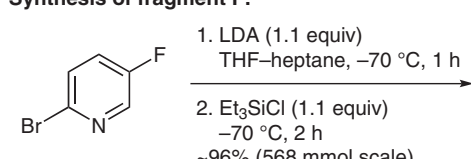

A

$\sim 96 \%$ (568 mmol scale)<smiles>Fc1cnc(Br)cc1C(F)(F)F</smiles>

brown oil

\section{LDA (1.3 equiv) . $-78^{\circ} \mathrm{C}, 105 \mathrm{~min}$ 2. $\mathrm{MeON}(\mathrm{Me}) \mathrm{Ac}$ (1.3 equiv) $-78{ }^{\circ} \mathrm{C}$ to r.t., $1 \mathrm{~h}$ 3. SGC $89 \%$ (438 mmol scale)} ${ }^{*}[]$ denotes a product used in the
next step without further purification.<smiles>CC(O)c1nc(Br)ccc1-n1cccn1</smiles><smiles>CC(=O)c1nc(Br)ccc1-n1cccn1</smiles><smiles>CC(=O)c1c(Br)cc(Br)c(C)c1F</smiles>

pyrazole (1.2 equiv) $\mathrm{K}_{2} \mathrm{CO}_{3}$ (3.0 equiv) $\mathrm{MeCN}, 72{ }^{\circ} \mathrm{C}, 16 \mathrm{~h}$; $392 \mathrm{mmol}$ scale
$\mathrm{HCl}$ then SGC; recryst ex MTBE

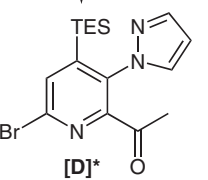

Synthesis of fragment $\mathrm{K}$ :

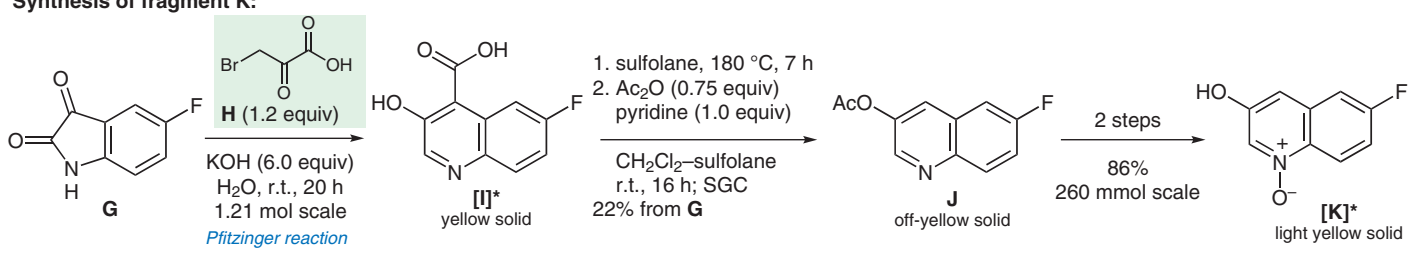<smiles>[X][n+]1cc(O)cc2cc(F)ccc21</smiles>

$$
\begin{gathered}
\mathbf{K}(2.0 \text { equiv }) \\
\mathbf{F}(1.0 \text { equiv }) \\
\mathrm{DIAD}(2.2 \text { equiv }) \\
\mathrm{Bu}_{3} \mathrm{P}(2.3 \text { equiv }) \\
\hline \underset{\mathrm{THF}, 0{ }^{\circ} \mathrm{C} \text { to r.t., o/n; }}{\mathrm{SGC}} \\
55.8 \mathrm{mmol} \text { scale } \\
\text { Mitsunobu reaction }
\end{gathered}
$$<smiles>CCc1nc(Br)ccc1-n1cccn1</smiles><smiles>CC(C)c1[nH]c(=O)ccc1-n1cccn1</smiles><smiles>COc1cc2cc(F)ccc2[n+]([O-])c1</smiles>
DIPEA (2.1 equiv) $\mathrm{NH}_{4} \mathrm{PF}_{6}$ (4.0 equiv) $\mathrm{CH}_{2} \mathrm{Cl}_{2},<-3.5^{\circ} \mathrm{C}$ to r.t., o/n; cryst ex EtOAc-heptane $75 \%$ (11.6 mmol scale) $\mathrm{Br}$<smiles>Cc1ccc(-n2cccn2)c(C(C)O)n1</smiles>

sickle cell anemia

biocatalysis

ketoreductase

Pfitzinger quinoline synthesis

Mitsunobu reaction

Significance: Sickle cell disease is a common genetic disorder that affects 15 million people worldwide. It is caused by a single point mutation on the $\beta$-chain of adult hemoglobin. PF-07059013 is a noncovalent modulator of hemoglobin that has entered phase I clinical trials for the treatment of sickle cell disease.
Comment: Key steps in the synthesis depicted are (1) the asymmetric reduction of ketone $\mathbf{E}$ using the ketoreductase KRED101 from Codexis to afford enantiopure $\mathbf{F}$ in $94 \%$ yield (>99\% ee), (2) the construction of quinoline I using a Pfitzinger reaction, and (3) a Mitsunobu reaction that links fragments F and $\mathbf{K}$. 